Life and loves of a Martian pioneer

\section{Peter Kemp}

Genesis: An Epic Poem. By Frederick Turner. Saybrook, 4223 Cole Avenue, Dallas, Texas 75205: 1988. Pp.303. Distributed by W.W. Norton, pbk $\$ 9.95$.

INSPIRED by such varied sources as Homer, James Lovelock's Gaia hypothesis, the Bible and the Wisconsin Arboretum's success in turning degraded farmland into prairie, Frederick Turner's Genesis is a work of considerable compass. Aiming to synthesize old and new, art and science, it tells in epic verse the story of the colonizing of Mars: as the settlers contrive to transform an arid planet into garden, Turner seeks to re-fertilize an apparently defunct genre.

His task is as risky as it is ambitious and, conscious of this, he equips his epic with defence mechanisms. This 10,000 line saga is, we are informed, the work of a twenty-first-century poet living under mild-ish totalitarian conditions then prevailing on Earth. A martyr to arthritis and despondency, he is painfully aware that his verse lacks polish. Also, we are warned that in the process of projecting it into Turner's cortex - exactly how is not explained - clumsiness may have crept in. Further intimating that the poem should be handled with kid gloves is a heartfelt evocation - "Poor sciencefiction. Last muse of the gods ..." lamenting the unjustly despised status of this type of writing. As a final deterrent against criticism, the poem features as its most repulsive character a reviewer who has "A Shiite mullah's openmindedness, /A moral backbone of boiled watercress;/All the prophetic vision of a sheep".

At risk of seeming such a mix of bigotry, salad and mutton, it has to be said that the poem is uneven. Its best stretches are its landscapes. Turner sensuously excels at evoking atmospheric terrains - from the wind-scorched Australian outback to Mars at different stages of its ecogenesis: the "golden furs and powdery crimsons" of mosses and lichens spreading over "glitterings of slime and foams", blossoms gorgeously exploding into newly oxygenated air.

But, along with this flair for dramatizing the processes of life-formation and evolution, goes an enfeebling inability to create and develop lifelike characters and situations. The poem is peopled by melodramatic puppets. Resembling the plastic personnel of some Star Wars, they range from evil Gaea, perfidious leader of the Ecotheist Movement, which teaches that nature must never be interfered with, to noble Chance, her estranged husband,

dedicated to bringing life to Mars. As battle-ships, a space Ark and a displaced ice moon of Saturn hurtle round the Solar System, freedom fighters, visionaries, gladiators, lurid villains and a miracleworking prophetess engage in comic-strip adventures.

Bizarrely, Turner's celebration of advanced biotechnology is studded with throwback violence: hand-to-hand fights, karate chops, disembowelling. Martial arts loom as large as Martian pioneering in his story. Incongruity keeps breaking through the attempt to combine sophisticated scientific lore with the barbarities traditional to epic literature: wars, parricide, split families, blood feuds, vengeance.

The poem's classic in medias res opening finds an appropriate out-of-this-world parallel to the Iliad: helmeted figures in metallic uniforms clash on the deadly plains of Mars. But despite the subsequent efforts to elevate proceedings by using the apparatus of the epic - heroic similes,

\section{We've got rhythm}

\section{Asa Briggs}

The Metronomic Society: Natural Rhythms and Human Timetables. By Michael Young. Thames \& Hudson/Harvard University Press: 1988 . Pp. 301. £16.95, \$25.

Michael Young, whose book The Rise of the Meritocracy fascinated readers a generation ago, has produced another remarkable and equally stimulating book which deals with even more basic issues. It is designed to be read by a wide audience, and it abounds in memorable phrases and descriptions. "Durability is not durability unless it is pulsating." "Habits are not usually chosen with any deliberation; they just grow, wild flowers rather than cultivated ones." "A habit is a memory unconsciously edited for action." "The fertility of nurture festoons itself around nature." "Time is immanent in everything You cannot catch it because you already have it." In the broadest sense this is a book for everybody, rich both in analogies and in insights. It deals in various degrees of detail with such topics as time, memory, tradition, habit and custom. It begins with an analysis, continues with a set of explanations and ends with a prescription.

The term "metronomic society" is not introduced until the end of the first chapter, where we are told that "modern society (and social science with it) . . . has a linear bias to it, and that with this linear bias many natural rhythms have been replaced by artificial ones, a rhythmic society replaced by a metronomic". The second chapter, which begins by noting how the living organism has long been one addresses to the muse, cataloguings of troops - bathos often intrudes. After an assassin returns from a mission to kill the Sibyl at her shrine in the Peacock mountain on Mars, it comes as an anti-climax to hear of his booking into a "clean hotel just west of Reading". Behaviour oscillates between the cosmically marvellous and the comically mundane. The switches of language also jar, with abrupt changes from laboratory terminology ("volatile calyptral ribosomes", "synthesized endorphins", "heterodyning frequencies") to musty archaisms ("And ruddy Phoebus gins to welke in west"). And it seems a shame that the twenty-first-century poet, though familiar with the intricate mechanisms of planetary engineering, has not always worked out ("tech-/Nical", "psych-/ Ologically", "choc-/Olate") how to fit his words neatly into pentameter lines.

Peter Kemp, 61 Princes Avenue, Finchley, London N3 2DA, UK, is lead fiction reviewer for the London Sunday Times.

of the favourite analogies for society, examines more fully the nature of the natural rhythms. It summarizes research, not all of it completely convincing, on an internal biological clock, while adding that it will not be conclusive until the clock or clocks shall be found.

Lord Young then turns to social behaviour and how it is timed, drawing the necessary contrasts both between natural rhythms and artificial rhythms and between animals and human beings: "bees and birds do not celebrate Sundays". Regularities, both natural and artificial, "create the social mesh", but "particularly within large and complex organisations, biological and social rhythms are in conflict with each other". The fourth chapter, "Habit: the Flywheel of Society", is the most original, although the term habit is used very generally to cover phenomena which are only differentiated at the end of the chapter (via the Encyclopedia of Social Science) into motor habits, cognitive habits, emotional habits and moral habits. It would have been more persuasive if the differentiation had been introduced from the outset, for the various activities that Lord Young uses as examples of habit suggest differences more than similarities. The conclusions are firm, however "Habit is a means of making learning stick"; "Habits constitute the rules of individual behaviour and customs the rules of social behaviour".

There is a darwinian ring to the last paragraph of the fourth chapter, which sets the scene for the following discussion of "Social Evolution". This is a less original chapter. It deals with speech, law and institutions, taking the British monarchy as the example, and notes how "despite and because of the hold of habit, institutions can evolve" and how in each 